\title{
Mineralization of residue from the drying of black pepper when applied to the soil
}

\author{
Mineralização dos resíduos provenientes da secagem da pimenta-do-reino quando aplicados ao \\ solo
}

Igor Rozado Bosa 1 (ORCID 0000-0002-3502-6011), Paola Alfonsa Vieira Lo Monaco 1 (ORCID 0000-0001-5498-7451), Ismail Ramalho Haddade 1 (ORCID 0000-0003-0303-8808), Gustavo Haddad Souza Vieira 1 (ORCID 0000-0001-9963-1571), Marcelo Rodrigo Krause 2 * (ORCID 0000-0002-7035-9030), Rodrigo Junior Nandorf 1 (ORCID 0000-0001-8771-9816)

${ }^{1}$ Instituto Federal do Espírito Santo, Santa Teresa, ES, Brasil.

2Universidade Federal de Viçosa, Viçosa, MG, Brasil. *Author for correspondence: agro.krause@gmail.com

Submission: 31/01/2021 | Acceptance: 15/10/2021

\begin{abstract}
The use of residues from the black pepper bean drying process as fertilizer for agricultural crops implies the need to know the dynamics of their decomposition and release of the nutrients to guide it's management, especially regarding the best time of its application in the soil. This study aimed to evaluate the dynamics of organic carbon and nitrogen during the mineralization process of this residue. The experiment was conducted in a completely randomized design with ten treatments related to different postdisposal periods to the soil $(0,7,13,20,27,34,48,69,98,147$ days). Samples were collected to quantify easily oxidized organic carbon (OCeo), organic nitrogen (ON) and the determinations of their respective mineralized fractions. The evaluation of OCeo mineralization, being more stable and less susceptible to climatic variations, was the most appropriate for estimating the mineralized fraction of the residue. The application of the residue in dystrophic Yellow Red Latosol soil during the month of August provides, after 140 days, OCeo and ON mineralized fractions around 99 and $60 \%$, respectively, in the climatic conditions of Espirito Santo state, Brazil.
\end{abstract}

KEYWORDS: black pepper residue, decomposition dynamics, fertilizer application.

\section{RESUMO}

A utilização de resíduos do processo de secagem de pimenta-do-reino como fertilizante de lavouras deve considerar a dinâmica de sua decomposição e liberação dos nutrientes, para orientar o seu manejo, principalmente quanto à melhor época de sua aplicação no solo. Este estudo teve como objetivo avaliar a dinâmica do carbono orgânico e do nitrogênio durante o processo de mineralização desse resíduo. $O$ experimento foi conduzido em delineamento inteiramente casualizado com dez tratamentos, correspondentes ao tempo de pós-disposição ao solo $(0,7,13,20,27,34,48,69,98,147$ dias), quando amostras foram coletadas para a determinação de carbono orgânico facilmente oxidado (OCeo), nitrogênio orgânico $(\mathrm{ON})$ e suas respectivas frações mineralizadas. A avaliação da mineralização do OCeo, por ser mais estável e menos suscetível às variações climáticas, foi a mais apropriada para a estimativa da fração mineralizada do resíduo. A aplicação do resíduo em solo de Latossolo Vermelho Amarelo distrófico durante o mês de agosto proporciona, após 140 dias, frações mineralizadas OCeo e ON em torno de 99 e 60\%, respectivamente, nas condições climáticas do estado do Espírito Santo, Brasil.

PALAVRAS-CHAVE: resíduo de pimenta-do-reino, dinâmica de decomposição, aplicação de fertilizantes.

\section{INTRODUCTION}

Black pepper (Piper nigrum L.) is a climbing plant of great productivity and one of the most valued condiments in the world. In the black pepper processing, in the stage in which dryers are used, a residue known as black pepper "moinha" is generated at the rate of $15.2 \mathrm{~g}$ for each kilogram of processed pepper. The "moinha" is composed of vegetal remains, such as leaves, branches, inflorescences and poorly formed grains that are separated in the dryer (GUISOLFI et al. 2020). The farmers remove this residue deposited under the dryer, store it, and later distribute it in the black pepper plantations because it contains nutrients. However, farmers are unaware of the rate of mineralization of this organic material in the soil. This 
information is important to plan the application in order to allow the synchronization of nutrient release with the times of greater demand for agricultural crops to maximize the absorption of nutrients (PITTA et al. 2012).

The agricultural utilization of these residues is an economical and environmentally viable alternative when the application rates are adequate to meet the needs of nutrients absorption of the crops (MATOS 2010).

The use of organic residues in agriculture as fertilizers, besides providing macro and micronutrients, also represents environmental protection and conservation of natural resources (MATOS 2010, SARKAR et al. 2020). This is because, among other benefits, the correct disposal of the residues in the soil improves the structure and stabilization of aggregates (ZHANG et al. 2020), increases total porosity (EDEN et al. 2020), improves physical-water conditions, increases water retention capacity (VIEIRA et al. 2021), and facilitates the complexation of toxic substances (LAURICELLA et al. 2020). On the other hand, if the residues are disposed above the supporting capacity of the soil and the need of the crops can generate environmental problems associated with the losses of nitrogen, besides the risk of allowing the salinization of agricultural soils (PEREIRA et al. 2015).

Therefore, some studies have been carried out to evaluate the mineralization and degradation of residues in the soil, with the mineralized fraction being an important variable in the selection of the doses to be applied to the soil (PAULA et al. 2013, PEREIRA et al. 2015, DINIZ et al. 2016). In addition, it is important to note that this is a complex process, which is influenced by a large number of factors that interfere with soil $\mathrm{C}$ and $\mathrm{N}$ dynamics, such as soil characteristics and climatic conditions (PAULA et al. 2013). BOSA et al. (2019) state that the application of coffee "moinha" in a Dystrophic Red-Yellow Latosol provided, after 147 days, organic carbon easily oxidable and organic nitrogen mineralized fractions around $88 \%$ and $36 \%$, respectively, under the same climatic conditions of this study.

Due to the lack of information on the dynamics of black pepper "moinha" mineralization in the soil, this study is essential since it makes the use and the correct time of application possible for these agricultural residues and others. Therefore, the objective of this study was to evaluate the dynamics of carbon and organic nitrogen during the process of mineralization of the residue from the drying process of black pepper beans (black pepper "moinha") when applied superficially to the soil.

\section{MATERIAL AND METHODS}

The experiment was carried out under field conditions, in a dystrophic Yellow Red Latosol (Table 1), at the Santa Teresa campus of Federal Institute of Espírito Santo (IFES), in the municipality of Santa Teresa (19०48' S, longitude $40^{\circ} 40^{\prime} \mathrm{W}$ and an altitude of $130 \mathrm{~m}$ ).

Table 1. Result of soil analysis for surface application of residues in a dystrophic Yellow Red Latosol.

\begin{tabular}{|c|c|c|c|c|c|c|c|c|c|c|c|c|c|}
\hline \multirow[t]{2}{*}{$\mathrm{pH}$} & M.0. & P rem & $\mathrm{P}^{1}$ & $\mathrm{~K}$ & $\mathrm{Ca}$ & $\mathrm{Mg}$ & $\mathrm{Al}$ & $\mathrm{H}+\mathrm{Al}$ & SB & $T$ & $\mathrm{t}$ & $\mathrm{m}$ & V \\
\hline & $\mathrm{g} \mathrm{dm}^{-3}$ & $\mathrm{mg} \mathrm{L}^{-1}$ & \multicolumn{2}{|c|}{$----m g ~ d m^{-3}---$} & \multicolumn{4}{|c|}{---- cmolc dm $^{-3}$} & \multicolumn{3}{|c|}{--- cmolc dm-3----- } & \multicolumn{2}{|c|}{---- \% ----- } \\
\hline 6.8 & 17.5 & 38.0 & 615.1 & 756.0 & 8.4 & 2.4 & 0.0 & 2.4 & 12.7 & 15.1 & 12.7 & 0.0 & 84.1 \\
\hline
\end{tabular}

$\mathrm{pH}$ in water; $\mathrm{P}-\mathrm{Na}-\mathrm{K}$, Mehlich 1 Extractor; $\mathrm{Ca}-\mathrm{Mg}-\mathrm{Al}-\mathrm{KCl}-1 \mathrm{~mol} \mathrm{~L}^{-1}$ Extractor; $\mathrm{H}+\mathrm{Al}-$ Calcium Acetate $0,5 \mathrm{~mol}$ $\mathrm{L}^{-1}-\mathrm{pH} 7,0$ Extractor.

The experiment was conducted in a completely randomized design, with ten treatments and four replicates, with the treatments composed of the different days after application (DAA) of the residue from drying the black pepper beans $(0,7,13,20,27,34,48,69,98$ and 147 days).

The residues was collected in a dryer of a farm located in the Municipality of São Mateus, Espirito Santo state, Brazil, and were used in the state in which they were collected, that is, without crushing or sieving.

The physical-chemical analysis consisted of the determination of the electrical conductivity (EC) through a bench conductivity meter. The chemical analysis consisted of the determination of the $\mathrm{pH}$ and the quantification of the content of easily oxidized organic carbon (OCeo), total organic carbon (TOC), total nitrogen $(T N)$, organic nitrogen $(\mathrm{ON})$, phosphorus $(P)$, potassium $(K)$, Sodium $(\mathrm{Na})$ and the $\mathrm{C} / \mathrm{N}$.

The $\mathrm{pH}$ values were determined using a bench-top $\mathrm{pH}$ meter. The OCeo content was determined by the method of hot oxidation of the samples. TOC was estimated (TOC $=O C e 0 / 0,77)$. TN was determined by the Kjeldahl method. ON was calculated by discounting the content of mineral forms $\left(\mathrm{N}^{-\mathrm{NH}_{4}}{ }^{+}\right.$and $\left.\mathrm{N}-\mathrm{NO}_{3}\right)$ of the TN value determined in each sampling. $\mathrm{P}$ was determined by spectrophotometry, and $\mathrm{K}$ and $\mathrm{Na}$ by the 
flame photometry. $\mathrm{C} / \mathrm{N}$ is the relation of TO and TN. All procedures are described by Matos (2015). Table 2 presents the chemical and physico-chemical characteristics of the black pepper "moinha" used in the experiment.

Table 2. Chemical and physico-chemical attributes of the black pepper "moinha" used in the experiment.

\begin{tabular}{|c|c|c|c|c|c|c|c|c|}
\hline \multirow[t]{2}{*}{$\mathrm{pH}$} & EC & OCeo & TOC & $\mathrm{TN}$ & $\mathrm{P}$ & $\mathrm{K}$ & $\mathrm{Na}$ & \multirow[t]{2}{*}{$\mathrm{C} / \mathrm{N}$} \\
\hline & $\mathrm{dS} \mathrm{m}^{-1}$ & & . & . & $\cdots$ & ....... & & \\
\hline 7.50 & 1.92 & 362.0 & 470.0 & 19.0 & 2.2 & 3.3 & 0.5 & 24.7 \\
\hline
\end{tabular}

pH-hydrogen potential in water; EC-electrical conductivity 1:2.5 (v:v); OCeo-easily oxidized organic carbon; TOC-total organic carbon; TN-total nitrogen; P-phosphorus; K-potassium; Na-sodium; C/N-carbon/nitrogen ratio.

The residue was inserted into the soil surface layer inside the cylinders (Figure 1(a)). The amount of residue applied to the soil was based on the required amount of Nitrogen for a production $6.0 \mathrm{Mg} \mathrm{ha}^{-1}$ of

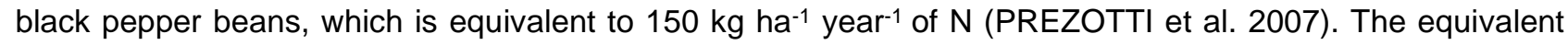
amounts applied per area were calculated assuming 2,240 Mg of soil per hectare (soil mass in 10,000 $\mathrm{m}^{2}$ for the 0-0.2 m depth layer and with a soil density of $1.12 \mathrm{~kg} \mathrm{dm}^{-3}$ ). Then, the amount of dry "moinha" applied to each ring was $24.79 \mathrm{~g}$, considering an amount of 7,894.7 $\mathrm{kg}$ of dry "moinha" per hectare. Finally, the mineralization process was carried out with the residue packaged in cylinders of PVC pipe rings $0.20 \mathrm{~m}$ in diameter and $0.05 \mathrm{~m}$ height, buried in the topsoil with holes in the edge to allow the movement of solutes between the two media (Figure 1(b)).

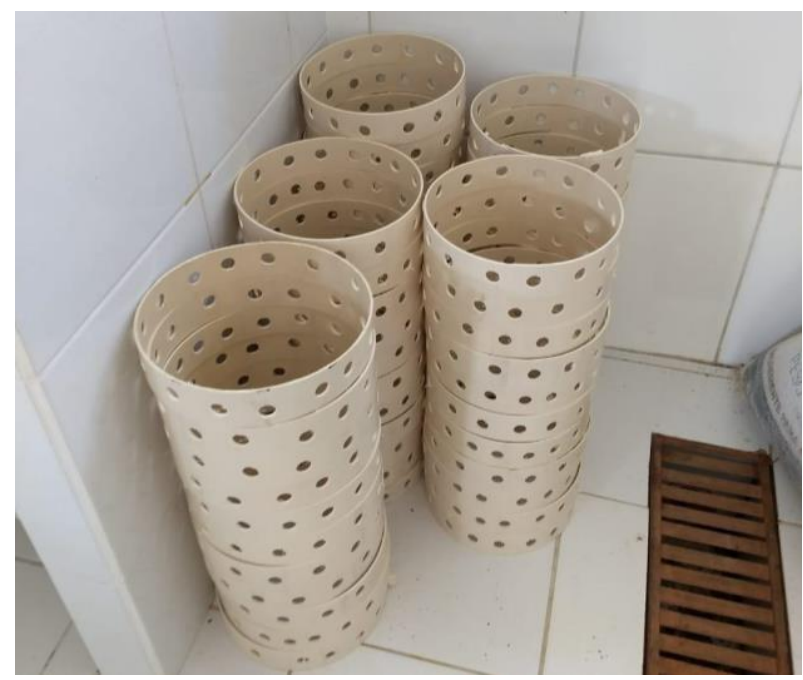

(a)

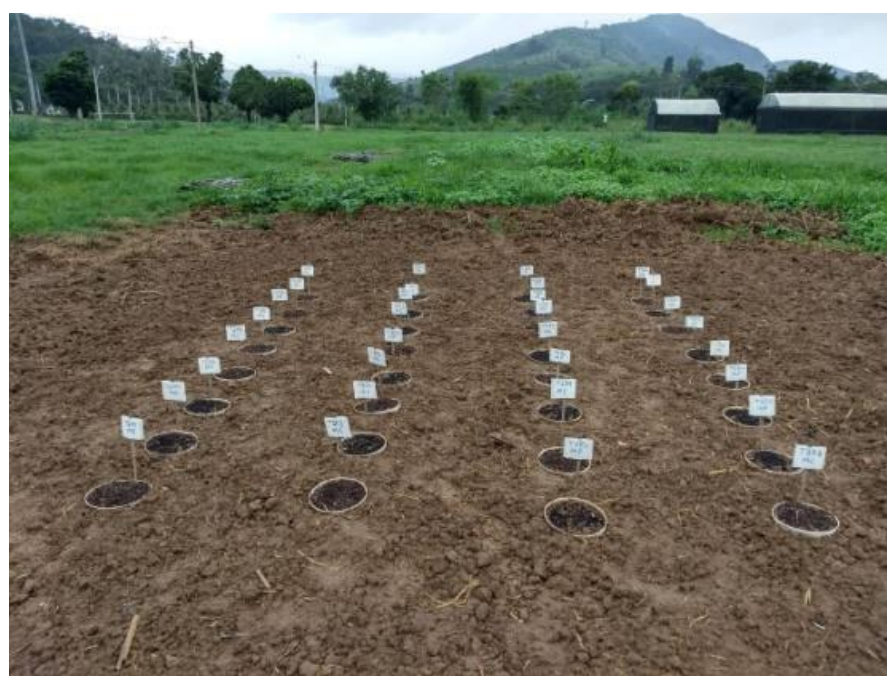

(b)

Figure 1. Perforated PVC cylinders used to condition the residue from the processing of black pepper beans in the soil (a) and detail of the disposal of the residue in the soil inside the cylinders (b).

Samples with approximately $100 \mathrm{~cm}^{3}$ of material were collected on the soil surface, inside de rings, using a spoon, at $0,7,13,20,27,34,48,69,98,147$ days after the experiment was set up to analyze the concentration of OCeo and TN, and inorganic nitrogen in the ammoniacal $\left(\mathrm{NH}^{4+}\right.$ ) and nitric $\left(\mathrm{NO}^{-3}\right)$ (MATOS 2015). Weeds were removed manually during the experiment

The OCeo and ON contents, obtained from 0 to 147 days, were used directly in Equation 1 and 2, respectively, to obtain the observed mineralized of $\mathrm{C}(\mathrm{MfOCeo}(\mathrm{ob}))$ and $\mathrm{N}(\mathrm{MfON}(\mathrm{ob}))$ fractions (PAULA et al. 2013).

$$
\text { MfOCeo }(\mathrm{ob})=100 \frac{[\mathrm{oCeo}(\mathrm{sr}) \mathrm{in}-\mathrm{OCeo}(\mathrm{s}) \mathrm{in}]-[\mathrm{oCeo}(\mathrm{sr}) \text { end-oCeo(s)end] }}{\text { OCeo(sr) in-OCeo(s)in }}
$$

where: $\mathrm{OCeo}(\mathrm{sr})$ in is easily oxidized organic $\mathrm{C}$ in the soil/residue at the beginning of the sample incubation period $\left(\mathrm{dag} \mathrm{kg}^{-1}\right)$; OCeo(sr)end is easily oxidized organic $\mathrm{C}$ in the soil/residue at the end of the sample incubation period (dag kg-1); OCeo(s)in is easily oxidized organic $C$ in the soil, at the beginning of the sample incubation period ( $\mathrm{dag} \mathrm{kg}^{-1}$ ); and OCeo(s)end is easily oxidized organic $\mathrm{C}$ in the soil at the end of the sample incubation period $\left(\mathrm{dag} \mathrm{kg}^{-1}\right)$. 


$$
\text { MfON(ob) }=100 \frac{\text { [oN(sr)in-oN(s)in]-[oN(sr)end-oN(s)end] }}{\text { ON(sr)in-ON(s)in }}
$$

where: $\mathrm{ON}(\mathrm{sr})$ in is organic $\mathrm{N}$ in the soil/residue at the beginning of the sample incubation period (dag $\mathrm{kg}^{-1}$ ); $\mathrm{ON}(\mathrm{sr})$ end is organic $\mathrm{N}$ in the soil/residue at the end of the sample incubation period (dag $\mathrm{kg}^{-1}$ ); $\mathrm{ON}(\mathrm{s})$ in is organic $\mathrm{N}$ in the soil at the beginning of the sample incubation period (dag kg-1); and ON(s)end is organic $\mathrm{N}$ in the soil at the end of the sample incubation period $\left(\mathrm{dag} \mathrm{kg}^{-1}\right)$.

Concentrations of $\mathrm{OCeo}(\mathrm{min})$ and $\mathrm{ON}(\mathrm{min})$ mineralized over time were obtained by the differences between the contents on the day the residue was applied (day zero) and those quantified on the date of each assessment. Climatic data of rainfall and temperature were collected during the months of August 2018 to January 2019, at the Santa Teresa IFES campus weather station (Figure 2).

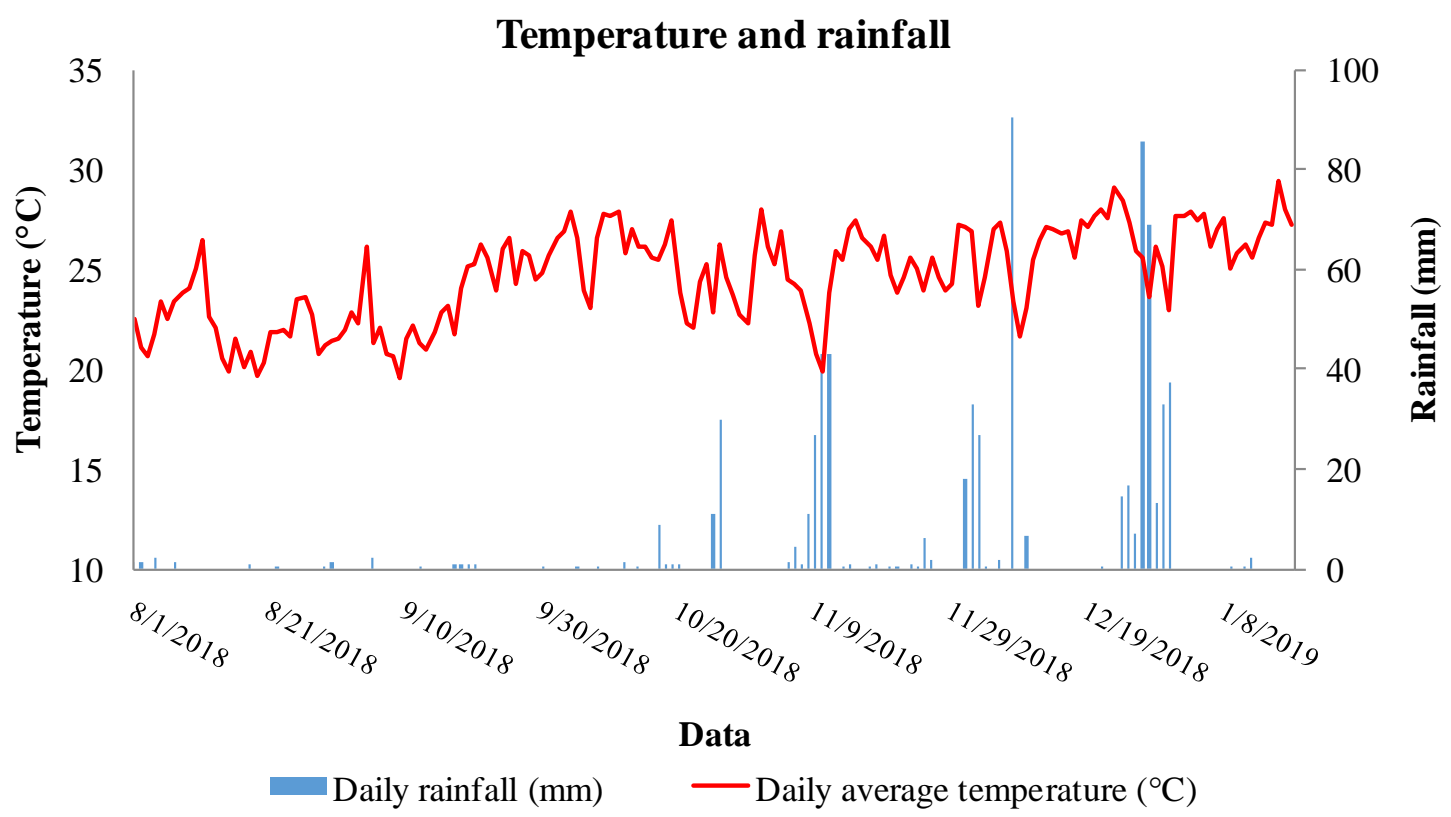

Figure 2. Temperature and rainfall data during the phase of monitoring the decomposition of the black pepper "moinha" arranged superficially in the soil.

The data were submitted to the Levene (Homoscedasticity) and Shapiro-Wilk (Normality) tests, and analyzed in a completely randomized design, with 10 treatments (referring to the post-conditioning of the residues in the cylinders) and four replicates, evaluated by analysis of linear regression. The regression equations were used to describe the behavior of $\mathrm{OC}$ and $\mathrm{ON}$ and their mineralized fractions during the postconditioning period in the soil. For all procedures an "a" of up to 0.01 was adopted.

\section{RESULTS AND DISCUSSION}

According to the results presented in Figure 3(a), the mineralization process promoted a linear decrease in the organic carbon of the black pepper "moinha" during the monitoring days. The decrease in the organic carbon content during mineralization was inherent to this process, as it was mainly due to the release of $\mathrm{CO}_{2}$ resulting from the respiration of the microorganisms responsible for the transformation of organic matter (KIEHL 2002).

Figure $3(\mathrm{~b})$ shows that the mineralized organic carbon fractions at $30,60,90,120$, and 140 days after application (DAA) were 26.6, 46.2, 65.9; 85.6, and 98.7\%, respectively. The mineralized fraction of organic carbon in this study was lower when compared with results obtained by other authors, although they used other residues. In the study of decomposition process of organic carbon (OC) and organic nitrogen (ON) from the peach palm residues under field and laboratory conditions and with two forms of application (with incorporation or surface soil disposal) was observed that the estimated mineralized fraction of OCeo was $50.98 \%$ after 28 days of incubation of the residue when it was applied superficially (PEREIRA et al. 2015). In analysis of different methods of estimating the mineralized fractions of cattle, pig, and poultry manures, as well as sewage sludge and urban residue compost in the field, when incorporated or disposed on a dystrophic Red-Yellow Latosol (LVAd) was verified that the estimated OCeo mineralized fractions were higher than $75.6 \%$ in the superficially disposed residues after 30 days of incubation of the residue. It is noteworthy that pig and poultry residues had a lower $\mathrm{C} / \mathrm{N}$ ratio, 12.76 and 6.41 , respectively, than in the present study (24.7), which contributed to the fast mineralization. 

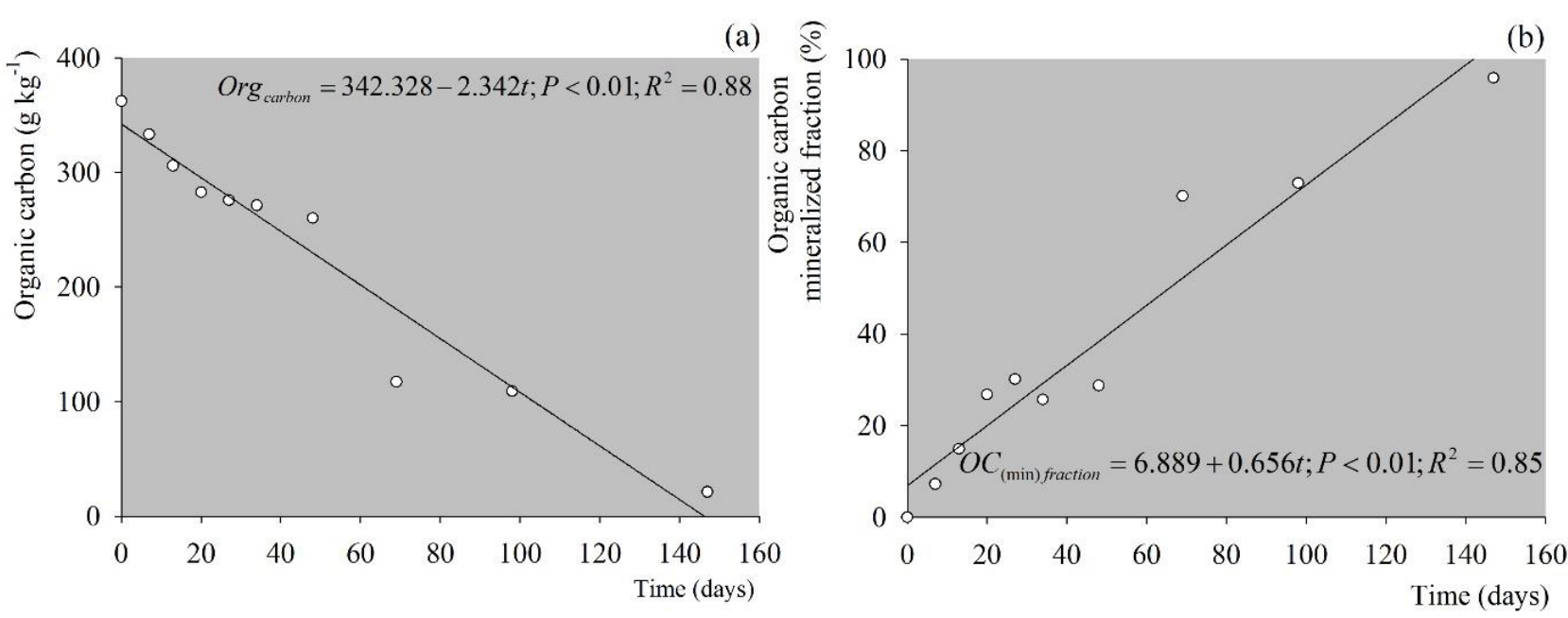

Figure 3. The content of organic carbon (a) and the mineralized organic carbon fractions (b) of the black pepper "moinha", along the degradation time in the soil.

Several factors interfere with the decomposition and mineralization of organic residues, including the $\mathrm{C} / \mathrm{N}$ ratio of the residues, physicochemical and biological characteristics, and soil temperature and moisture (FIGUEIREDO et al. 2012). The longer time required for the mineralization of the black pepper "moinha" organic carbon could be associated mainly with the climatic conditions that occurred during the monitoring period, mainly in August and September. According to Figure 2, there was no rainfall during these months, thus delaying the mineralization process. In addition, the characteristics of the residue, such as the presence of tannins and lignified fibers of the black pepper "moinha", may have contributed to the microorganisms having greater difficulty in degrading this material.

There is a wide variety of special metabolites present in the Piper nigrum species, which are distributed in different classes of compounds: amides/alkaloids, propenylphenols, lignans, neoliganans, terpenes, flavones and miscellaneous compounds, some of which are found only in this species (PARMAR et al. 1997). Among the amides/alkaloids, that piperine is the major metabolite of the species $P$. nigrum, possessing several biological activities, including insecticide, nematicide and antiparasitic (PISSINATE 2006).

As for organic nitrogen mineralization (Figure 4(a)), there was also a decreasing linear trend; however, the function adjusted to the data had a low coefficient of determination due to the high instability of this variable, making it difficult to estimate the mineralized fraction (Figure 4(b)). This fact has also been verified in the mineralization of various residues in the soil (PAULA et al. 2013, PEREIRA et al. 2015). The levels of inorganic nitrogen and, consequently, organic nitrogen, are subject to the strong influence of climatic variations and for this reason, have generated unreliable estimates of the mineralized fraction of the organic residues (PAULA et al. 2013). Thus, OCeo is the most indicated reference for use to evaluate organic residue (PEREIRA et al. 2015).
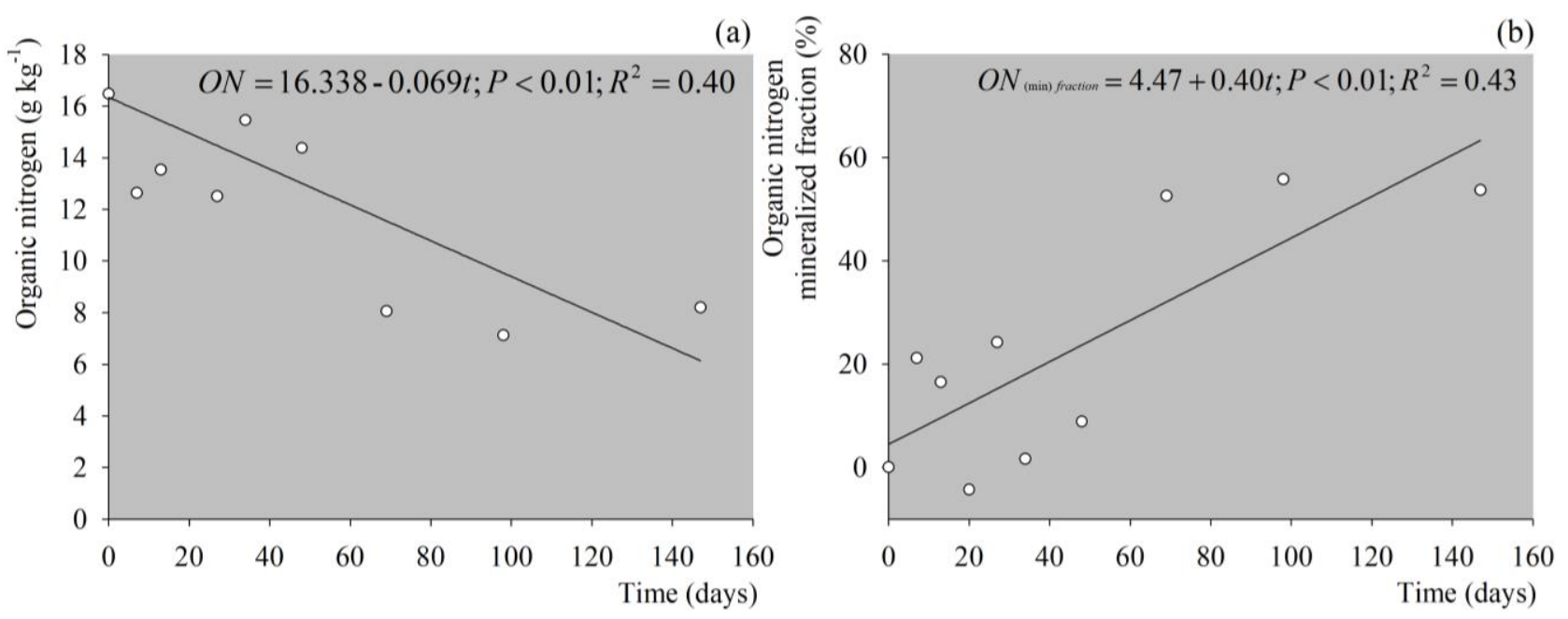

Figure 4. The content of organic nitrogen (a) and mineralized organic nitrogen fractions (b) of the black pepper "moinha", during the soil degradation time. 
Figure 4(b) shows that the mineralized fraction of organic nitrogen became larger after 70 days, as was the case with carbon, and coincided with the beginning of rainfall (Figure 2), showing the effect of soil moisture on mineralization of N (PAULA et al. 2013) and C (HUANG \& HALL 2017) carried out by microorganisms

At the end of 140 days of monitoring, the organic nitrogen mineralized fraction reached about $60 \%$. These results suggest that the black pepper "moinha" has great mineralization capacity. Under conditions similar to coffee straw after 150 days it presented mineralization values of $36 \%$ of organic nitrogen (BOSA et al. 2019). On the other hand, in studies carried out by Paula et al. (2013), the OC and ON mineralized fractions of manure from cattle, swine and poultry were, after 120 days, higher than $89 \%$, a value higher than that obtained in this study (60\%). This fact suggests that the form of nitrogen present in the residue influences the mineralization process in addition to the climatic influence. According to Carneiro et al. (2013), the contents of total- $\mathrm{N}$, the forms of $\mathrm{N}$ and the degree of humification of organic residues can influence different speeds of mineralization. Most of the total nitrogen in residue in solid form is in ammoniacal form (OLIVEIRA 1993), while the black pepper "moinha" is in organic form (Table 1).

Thus, if the farmer disposes of the residue in pepper plants in the month of August, it will provide, after 140 days, OC and ON mineralized fractions around 99 and $60 \%$, respectively, under the climatic conditions of the mountain region of Espirito Santo state. In soils cultivated with eucalyptus, the greater mineralization of $C$ in relation to that of $N$, for the same analyzed intervals, was also verified by Barreto et al. (2010). This result allows better planning of fertilizer applications, with the aim to match the release of nutrients with the time of greatest demand for the crops in which these residues will be applied.

\section{CONCLUSION}

The evaluation of OCeo mineralization, because it is more stable and less susceptible to climatic variations, is most appropriate for estimating the mineralized fraction of the residue than the ON mineralization.

The application of the black pepper "moinha" in Dystrophic Yellow Red Latosol during the month of August provides, after 140 days, OCeo and ON mineralized fractions around 99 and $60 \%$, respectively, in the climatic conditions of the mountain region of the Espirito Santo state, Brazil.

\section{ACKNOWLEDGEMENTS}

The authors thank the "Sítio Nova Esperança" for the concession of the black pepper "moinha", the FAPES for financial support and the Federal Institute of Espírito Santo Research and Postgraduate Deanship Scientific Dissemination Program (PRODIF) for assistance in translating this manuscript.

\section{REFERENCES}

BOSA IR et al. 2019. Coffee straw mineralization applied to the soil surface. Emirates Journal of Food and Agriculture $31: 380-385$.

BARRETO PAB et al. 2010. Carbon and nitrogen mineralization in soils under an eucalyptus plantation chronosequence. Revista Brasileira de Ciência do Solo 34: 735-745.

CARNEIRO WJO et al. 2013. Mineralização de nitrogênio em latossolos adubados com resíduos orgânicos. Revista Brasileira de Ciência do Solo 37: 715-725.

DINIZ ICC et al. 2016. Degradation of sewage sludge compost disposed on the soil. Engenharia Agrícola 36: 822-829.

EDEN M et al. 2020. Soil structure of a clay loam as affected by long-term tillage and residue management. Soil and Tillage Research 204: 104734.

FIGUEIREDO CC et al. 2012. Mineralização de esterco de ovinos e sua influência na produção de alface. Horticultura Brasileira 30: 175-179.

GUISOLFI LP et al. 2020. Agricultural wastes as alternative substrates in the production of conilon coffee seedlings. Bioscience Journal 36: 792-798.

HUANG W \& HALL SJ. 2017. Elevated moisture stimulates carbon loss from mineral soils by releasing protected organic matter. Nature Communications 8: 1-10

KIEHL EJ. 2002. Manual de compostagem: Maturação e qualidade do composto. 3.ed. 171p.

LAURICELLA D et al. 2020. Effectiveness of innovative organic amendments in acid soils depends on their ability to supply P and alleviate Al and Mn toxicity in plants. Journal of Soils Sediments 20: 3951-3962.

MATOS AT. 2010. Poluição ambiental - Impactos no meio físico. 1.ed. Viçosa: UFV.

MATOS AT. 2015. Manual de análise de resíduos sólidos e águas residuárias. 1.ed. Viçosa: UFV.

OLIVEIRA PAV. 1993. Manual de manejo e utilização dos dejetos de suínos. EMBRAPA-CNPSA. Documentos 27. $188 p$. 
PARMAR VS et al. 1997. Phytochemistry of the Genus Piper. Phytochemistry 46: 597-673.

PAULA JR et al. 2013. Mineralização do carbono e nitrogênio de resíduos aplicados ao solo em campo. Revista Brasileira de Ciência do Solo 37: 1729-1741.

PEREIRA MS et al. 2015. Mineralização do resíduo da pupunheira em condições de campo e laboratório. Engenharia Agrícola 35: 918-930.

PISSINATE K. 2006. Atividade citotóxica de Piper nigrum e Struthanthus marginatus. Estudo preliminar da correlação entre a citotoxicidade e hidrofobicidade da piperina e derivados sintéticos. Dissertation (Master of Science). Rio de Janeiro: UFRRJ. 110p.

PITTA CSR et al. 2012. Year-round poultry litter decomposition and N, P, K and Ca release. Revista Brasileira de Ciência do Solo 36: 1043-1053.

PREZOTTI LC et al. 2007. Manual de recomendação de calagem e adubação para o Estado do Espírito Santo: 5a aproximação. Vitória: SEEA/INCAPER/CEDAGRO.

SARKAR S et al. 2020. Management of crop residues for improving input use efficiency and agricultural sustainability. Sustainability $12: 9808$.

VIEIRA GHS et al. 2021. Surface residues: effects on soil moisture and temperature. Caatinga 34: 887-894.

ZHANG W et al. 2020. Residue incorporation enhances the effect of subsoiling on soil structure and increases SOC accumulation. Journal of Soils Sediments 20: 3537-3547. 